\title{
Review
}

Source: Journal of Ecology, Vol. 3, No. 3 (Sep., 1915), p. 192

Published by: British Ecological Society

Stable URL: http://www.jstor.org/stable/2255397

Accessed: 05-06-2016 14:14 UTC

Your use of the JSTOR archive indicates your acceptance of the Terms \& Conditions of Use, available at

http://about.jstor.org/terms

JSTOR is a not-for-profit service that helps scholars, researchers, and students discover, use, and build upon a wide range of content in a trusted digital archive. We use information technology and tools to increase productivity and facilitate new forms of scholarship. For more information about JSTOR, please contact support@jstor.org.

Wiley, British Ecological Society are collaborating with JSTOR to digitize, preserve and extend access to Journal of Ecology 
where Fagus cliffortioides is the forest. Above the forest zone, the entire absence of Ligusticum dissectum, the most abundant plant of the Tararuas above $4000 \mathrm{ft}$., is striking; on the other hand, two abundant plants of the Ruahine tops, Celmisia incana and Dracophyllum recurvum, are not represented on the Tararua range. A great feature of the tussock-meadow is the abundance of Celmisia spectabilis and $C$. incana, the mountain-side being white with their flowers when seen from a distance of 5 miles or more. Various differences between the Ruahine and Tararua ranges are indicated, the author pointing out that certain plants on each range appear to play the rôle in the vegetation played by other species on the other range.

\section{VEGETATION OF BRITISH COLUMBIA}

Davidson, J. "First and Second Reports of the Botanical Office of the Province of British Columbia." Victoria, B. C., 1914 and 1915, pp. 1-30, 31-76, figs. 1-61.

These two reports contain much that is of interest to the plant geographer, since they furnish indications of the rich field for more detailed and more definitely ecological work which lies open to botanists in the western province of the Dominion of Canada, and of the excellent beginning which has been made in this direction despite the difficulties encountered by the energetic Provincial Botanist and his co-workers in the botanical exploration of the province. British Columbia is essentially a mountainous country, since the Rocky Mountains which in the United States lie to the east of the Great Basin, on running to the north bear towards the west and approach the ranges bordering the Pacific coast. The province comprises practically the whole width of the Cordilleran belt between $49^{\circ}$ and $60^{\circ} \mathrm{N}$. lat., with two main mountain chains-the Rocky Mountains proper on the north-east side and the Coast Range on the south-west (Pacific) sidebetween which are several subordinate ranges as well as the elevated tract of hilly country (the so-called "Interior Plateau") with summits of accordant altitude.

The reports are largely concerned with administrative and floristic work, but interesting accounts are given of expeditions made to some of the higher portions of the province which show a rich development of alpine and subalpine vegetation. Since the descriptions are given in the form of itineraries of the routes followed, it is difficult to summarise them, but the general character of the vegetation may be judged by the numerous and excellent photographic illustrations which accompany the reports and of which we are, through the kindness of the author and the courtesy of the Government of British Columbia, enabled to reproduce a selection (Plates XIV-XVII). Moreover, the author proposes in the near future to issue bulletins dealing more fully with the plant communities, so that the accounts now given are, like that recently published on the forests of British Columbia (see this Journal, 1, 1913, p. 311, Plates XXV, XXVI), of a general and preliminary nature. It will be interesting to see the results obtained by the working out of the plant communities on an ecological survey plan, including the mapping of the vegetation, the distinguishing of the various vegetation types, the correlation of their distribution with the various climatic and edaphic factors, and the comparison of the subalpine and alpine formations of British Columbia with those developed in the more southerly portion of the Rocky Mountain range and worked at by American observers (see summary in this Journal, 2, 1914, p. 139). 


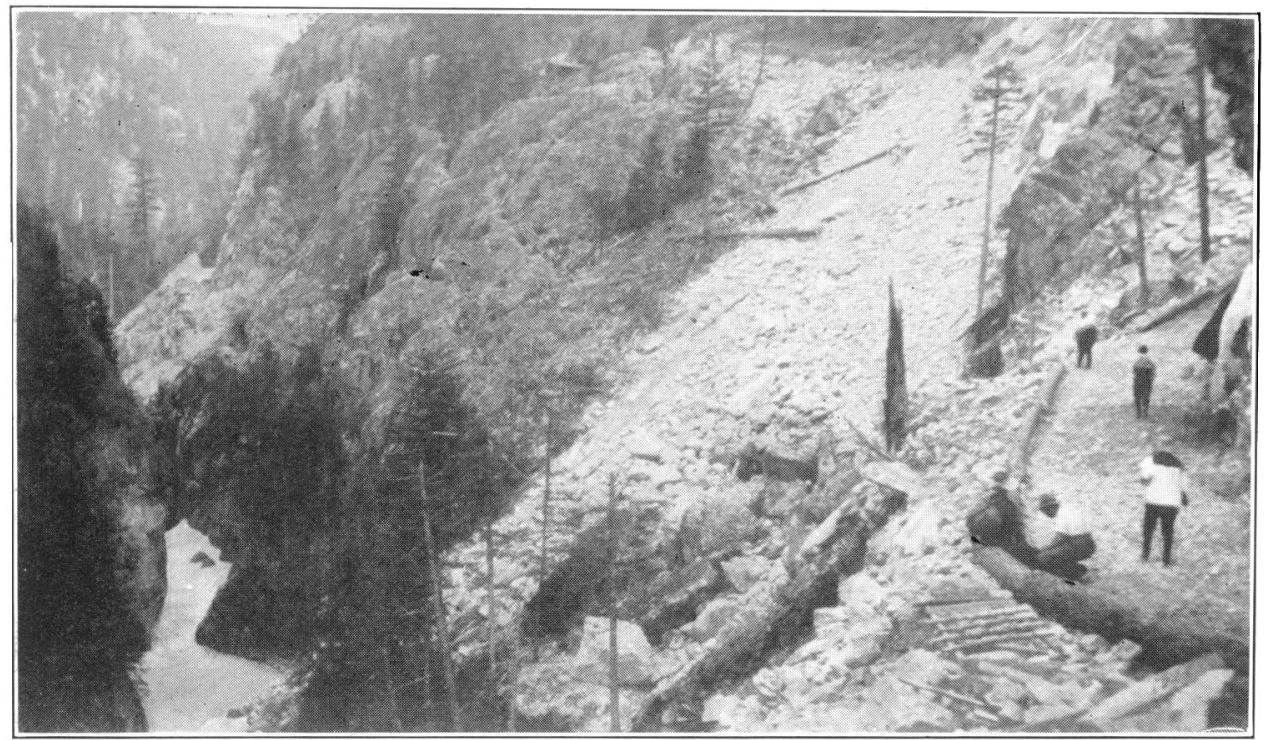

Cheakamus Canyon. The river opens into Howe Sound, and one of its feeders is Stony Creek (see photograph below); the banks bear dense coniferous forest, mostly Tsuga.

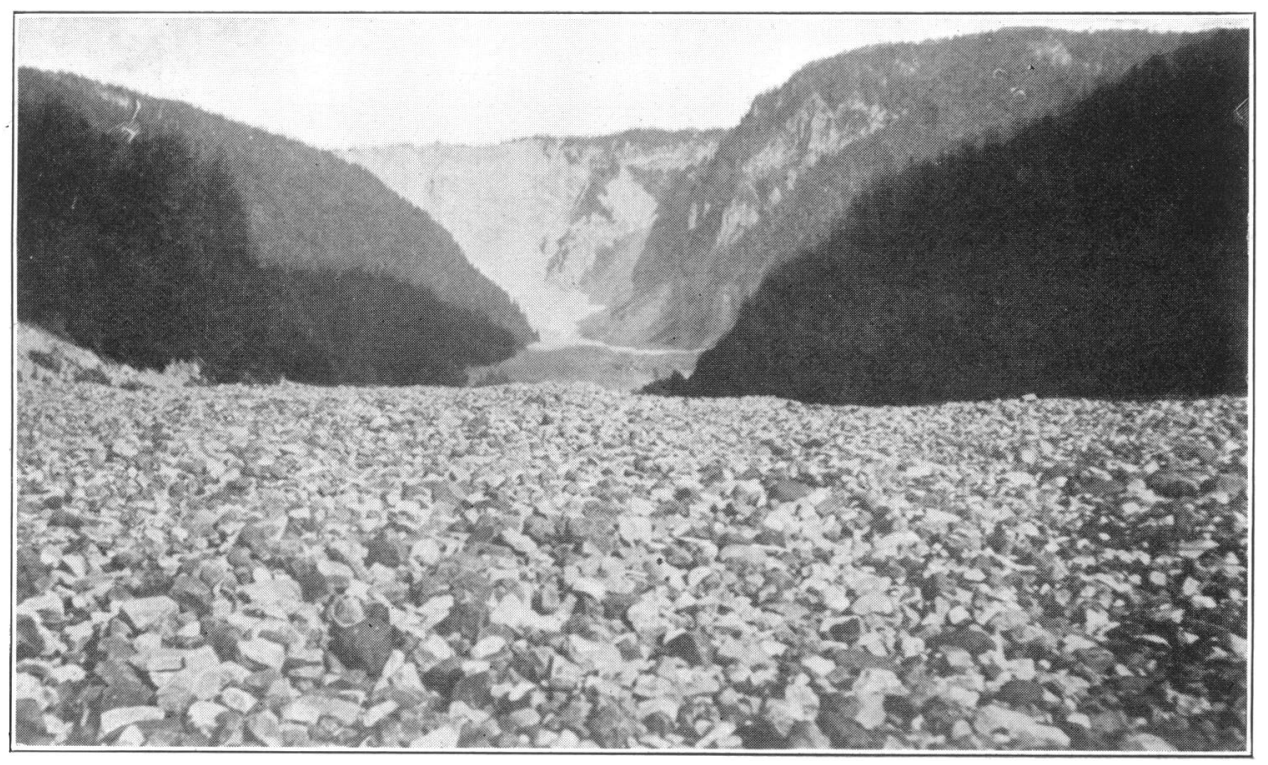

View of Stony Creek, with barrier ridge in the distance, beyond which is the alpine Lake Garibaldi ( $4600 \mathrm{ft}$.) surrounded on north, east and south by glaciers and snowfields. The slopes bear dense forests of Tsuga, Abies, Chamaecyparis, etc.

\section{Vegetation of British Columbia (p. ig2).}



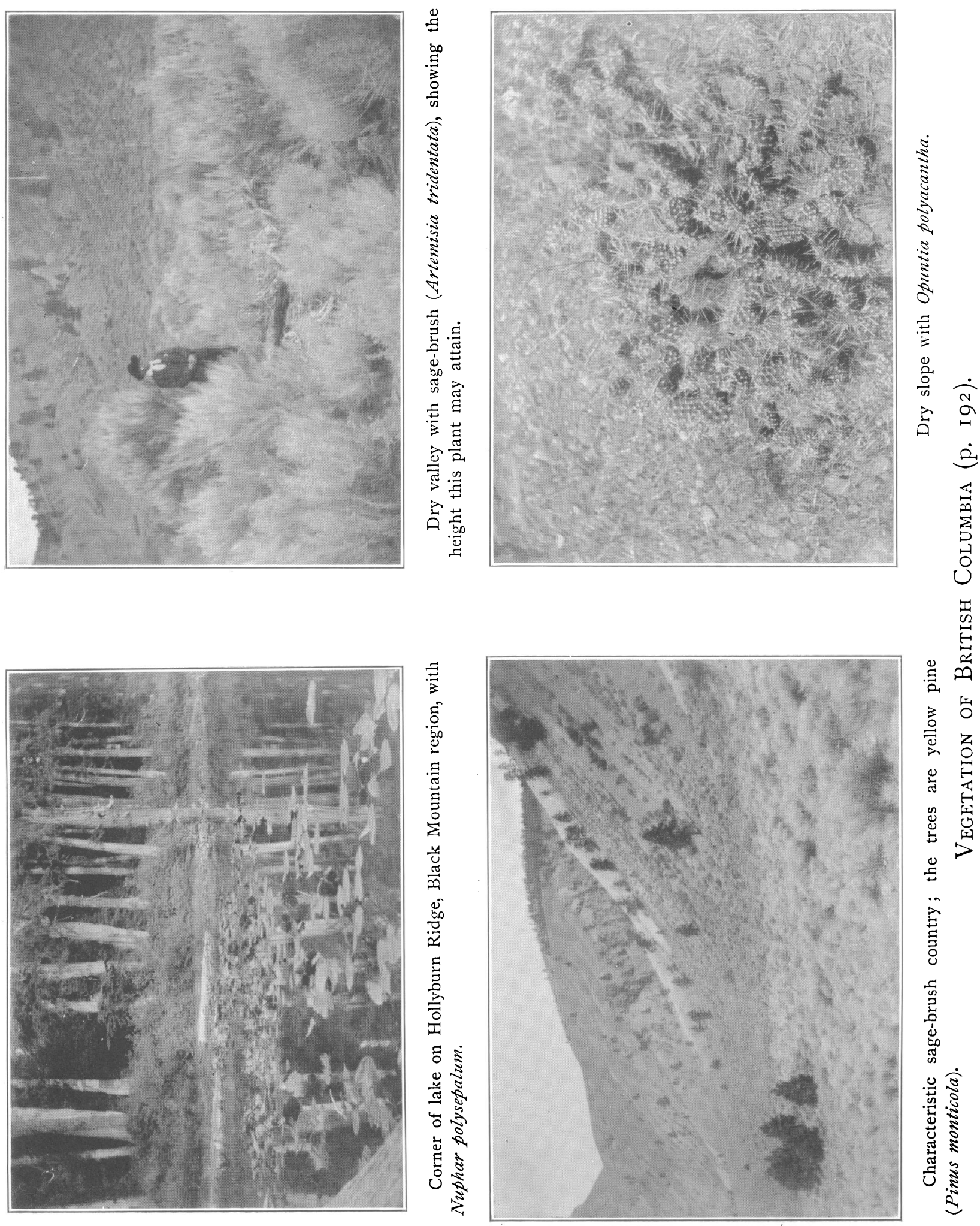

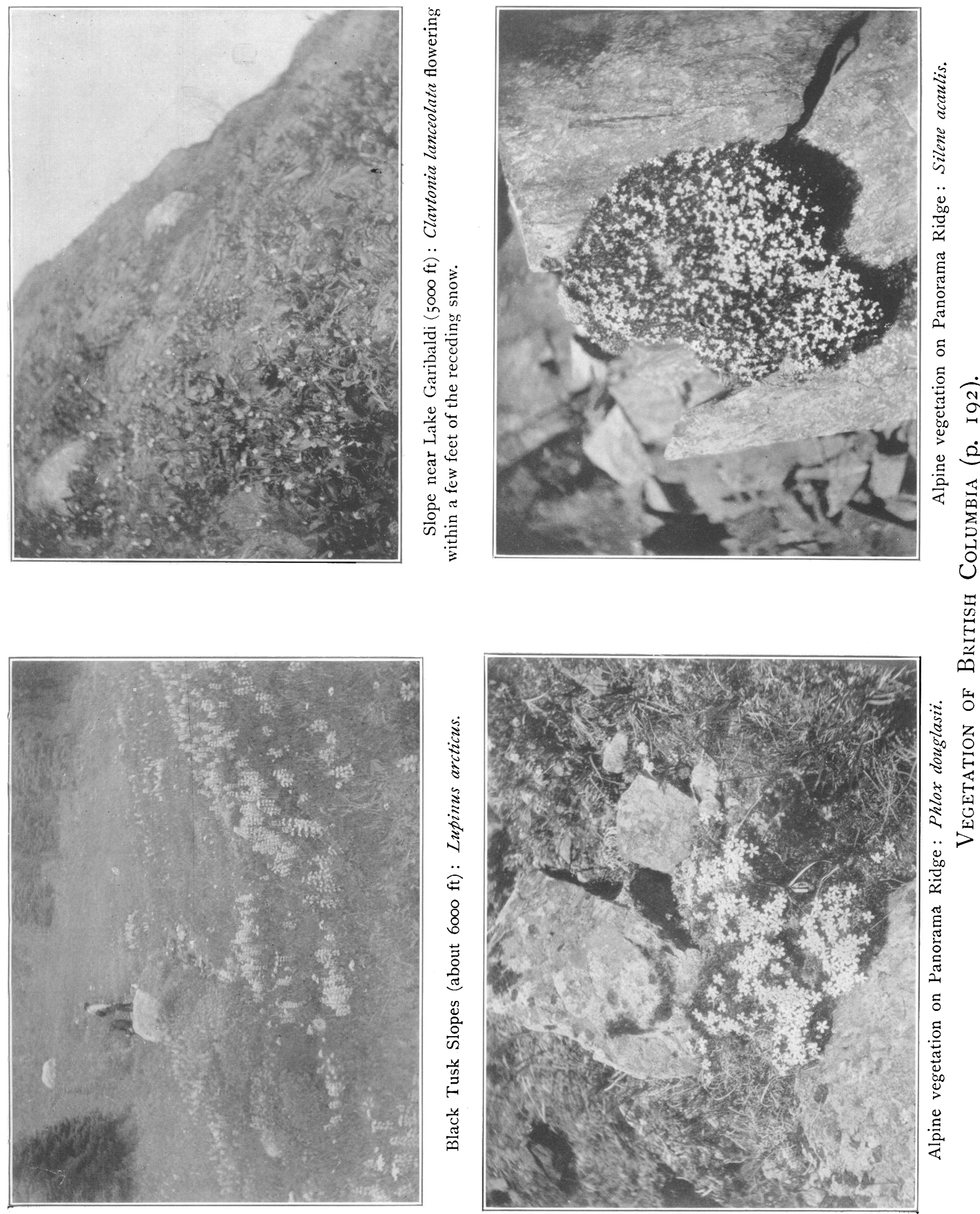

先

$\dot{2}$

$\therefore 5$

8

点

乐

हัँ

西

б

离

8

芩 

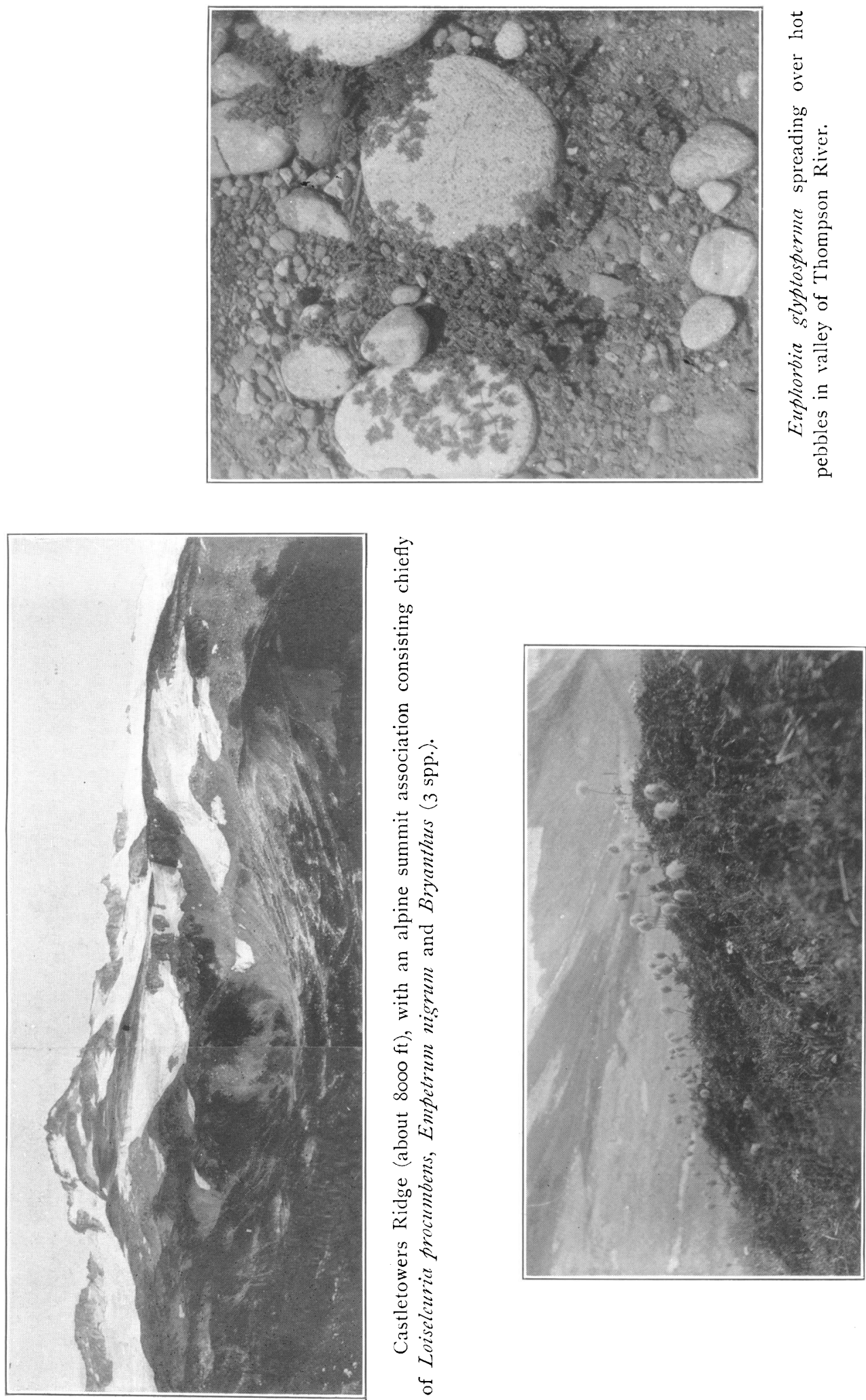